\title{
Prevalence of Obesity in Black Subjects with Type 2 Diabetes in Benin
}

\author{
Finangnon Armand Wanvoegbe1,2*, Kouessi Anthelme Agbodandé3, \\ Daniel Amoussou-Guénou 1,3, Adebayo Alassani', Léopold Codjo4, Alihonou Dansou ${ }^{2}$, \\ Yessoufou Tchabi ${ }^{3}$, Yasmine Eyissè ${ }^{3}$, Latif Mousse ${ }^{3}$ \\ ${ }^{1}$ Banque d'Insuline, Cotonou, Benin \\ ${ }^{2}$ Departmental University Hospital of Ouémé Plateau, Porto-Novo, Benin \\ ${ }^{3}$ The Polyclinic of Atinkanmey, Cotonou, Benin \\ ${ }^{4}$ Departmental University Hospital of Borgou, Alibori, Benin \\ Email: *wafinarm@yahoo.fr, agbotem@yahoo.fr, danielamousguen@yahoo.fr, alsaco2007@yahoo.fr, \\ leostelles@yahoo.fr, alihonoud87@yahoo.fr, youftchabi@yahoo.fr, minayisse@hotmail.com, \\ victorymousse@yahoo.fr
}

Received 28 June 2016; accepted 8 August 2016; published 11 August 2016

Copyright (C) 2016 by authors and Scientific Research Publishing Inc.

This work is licensed under the Creative Commons Attribution International License (CC BY).

http://creativecommons.org/licenses/by/4.0/

(c) (i) Open Access

\section{Abstract}

Background: Abdominal obesity is often associated with type 2 diabetes, especially in the context of metabolic syndrome. The objective of this study was to determine the prevalence of corpuscular and abdominal obesity in type 2 diabetes in the two major cities in southern Benin. Methods: It was a multicentric, prospective, descriptive and analytical study that had as framework the center for screening and monitoring of diabetes "Banque d'insuline" of Cotonou, the Polyclinic Atinkanmey of Cotonou and the Internal Medicine Department of the Departmental University Hospital of Ouémé-Plateau in Porto-Novo. The study was a six-month period (March-August 2014). Results: We included a total of 400 type 2 diabetics. Women represented $66 \%$ of the study population with a sex ratio of 0.52 . The mean age of patients was $55.6 \pm 10.3$ years with extremes of 28 and 87 years. The prevalence of corpuscular obesity (BMI $\geq 30 \mathrm{Kg} / \mathrm{m}^{2}$ ) was $38.5 \%$ in our study population. For the gender, it was $48.5 \%$ in women and $19.1 \%$ in men with a statistically significant difference $(p=0.0001)$. The overall prevalence of abdominal obesity in our study population was $87.8 \%$. Almost all of our diabetic women $(99.2 \%)$ had abdominal obesity versus $65.4 \%$ in men ( $p=$ 0.0001). All the patients with type 2 diabetes having corpuscular obesity had also abdominal obesity. This abdominal obesity was observed in $80.1 \%$ of non-obese diabetic $(p=0.0001)$. On the contrary, the majority of patients with abdominal obesity $(56.12 \%)$ had a BMI below $30 \mathrm{~kg} / \mathrm{m}^{2}$. Conclusion: This study shows a high prevalence of abdominal obesity $(87.8 \%)$ in our study population compared with the corpuscular obesity (38.5\%). Hence, the importance of measuring waist circumference is more than BMI in diabetic patients.

\footnotetext{
${ }^{*}$ Corresponding author.
}

How to cite this paper: Wanvoegbe, F.A., Agbodandé, K.A., Amoussou-Guénou, D., Alassani, A., Codjo, L., Dansou, A., Tchabi, Y., Eyissè, Y. and Mousse, L. (2016) Prevalence of Obesity in Black Subjects with Type 2 Diabetes in Benin. Open Journal of Internal Medicine, 6, 72-76. http://dx.doi.org/10.4236/ojim.2016.63012 


\section{Keywords}

\section{Obesity, Diabetes, Prevalence, Benin}

\section{Introduction}

Abdominal obesity is often associated with type 2 diabetes, especially in the context of metabolic syndrome. Although many diabetics are obese, all obese people are not diabetic, and there are also non-obese diabetic. Hence it is important for us to study the prevalence of obesity in diabetics in Benin, where the prevalence of diabetes is steadily increasing [1]-[3] like in other countries around the world [4]. Moreover, being a cardiovascular risk factor, obesity constitutes a co-morbidity in the diabetics and thus accelerates the development of diabetes complications particularly the macrovascular complications.

The mean BMI in a population of diabetics in Kinshasa was $23.992 \pm 5.413 \mathrm{~kg} / \mathrm{m}^{2}$ in 2009 [5]. In a study of sleep apnea syndrome in type 2 diabetes subjects in Benin, Amoussou-Guénou et al. have noted a corpuscular obesity prevalence of $44.3 \%$ in 2014 [6]. Seventy nine (79) patients were included in this study.

The objective of this study was to determine the prevalence of corpuscular obesity and abdominal obesity in type 2 diabetics in the two major cities of southern Benin.

\section{Methods}

This was a multicentric, prospective, descriptive and analytical study which had a framework the center for screening and monitoring of diabetes "Banque d'Insuline" of Cotonou, the Polyclinic Atinkanmey of Cotonou and the Internal Medicine Department of the Departmental University Hospital of Ouémé Plateau (CHUD-OP) in Porto Novo. The study is a six-month period (March-August 2014), and included all type 2 diabetics consulted during the period and who consented. We have therefore included a total of 400 type 2 diabetics.

The waist circumference was measured between the iliac crest and the last rib at a standing position. Abdominal obesity (IDF 2005) was defined by a waist circumference $\geq$ to $94 \mathrm{~cm}$ in men and $80 \mathrm{~cm}$ in women.

For the BMI (WHO): Normal: 18 to $24.99 \mathrm{~kg} / \mathrm{m}^{2}$; Overweight: 25 to $29.99 \mathrm{~kg} / \mathrm{m}^{2}$; Obesity grade 1:30 to 34.99 $\mathrm{kg} / \mathrm{m}^{2}$; Obesity grade $2: 35-39.99 \mathrm{~kg} / \mathrm{m}^{2}$; Obesity grade $3: \geq 40 \mathrm{~kg} / \mathrm{m}^{2}$. Diabetes is said to be balanced if the glycated hemoglobin $(\mathrm{HbAlc})$ is less than $7 \%$ and unbalanced if it is $\geq$ to $7 \%$.

Data entry and statistical analysis were made by Excel and Epi Info version 3.5.1 software. Chi-squared test was used to compare qualitative variables with a degree of significance of $\mathrm{p}<0.05$.

\section{Results}

\subsection{Population Characteristics}

Women represent $66 \%$ of the study population. The sex ratio is 0.52 . The mean age of patients was $55.6 \pm 10.3$ years with extremes of 28 and 87 years. 380 patients (95\%) lived in urban areas. Trade was the most represented profession with a proportion of 52.5\%. 390 patients $(79.8 \%$ ) lived in couple. Diabetes was balanced (HbA1c < $7 \%$ ) in $31.28 \%$ of 243 patients who have achieved HbAlc, then unbalanced at $68.72 \%$. Hypertension was present in $70 \%$ of this study population. The development of diabetes in patients ranges from 1 to 33 years with a mean of $8.27 \pm 6.78$ years. Dyslipidemia was present in 111 of 400 patients was $27.75 \%$.

\subsection{Prevalence of Corpuscular Obesity (BMI)}

The mean BMI was $26.83 \pm 4.62 \mathrm{~kg} / \mathrm{m}^{2}$ with a range of 16.30 and $46.79 \mathrm{~kg} / \mathrm{m}^{2}$ in men and $30.29 \pm 5.74 \mathrm{~kg} / \mathrm{m}^{2}$ with a range of 19.15 and $56.01 \mathrm{~kg} / \mathrm{m}^{2}$ in women. The difference is statistically significant with $\mathrm{p}=0.0001$.

According to the distribution depending on the class of BMI, this predominance is also noted for overweight women $(\mathrm{p}=0.0001)$ than in men (Figure 1$)$.

The prevalence of corpuscular obesity $(\mathrm{BMI} \geq 30)$ was $38.5 \%$ in the overall population. For the gender, it was $48.5 \%$ among women and $19.1 \%$ among men with a statistically significant difference $(p=0.0001)$ (Table 1$)$. 


\subsection{Prevalence of Abdominal Obesity}

The mean waist circumference was $97.93 \pm 14.12 \mathrm{~cm}$ with a range of 62.50 and $181.00 \mathrm{~cm}$ for men and $98.89 \pm$ $12.15 \mathrm{~cm}$ with extremes of 66.00 and 150.00 in women.

Table 1 shows that virtually all women with diabetes (99.2\%) had abdominal obesity versus $654 \%$ in men (p = $0.0001)$. The overall prevalence of abdominal obesity in our study population was $87.8 \%$.

Table 2 shows that all type 2 diabetics with corpuscular obesity (BMI $\geq 30 \mathrm{Kg} / \mathrm{m}^{2}$ ) had abdominal obesity. This abdominal obesity was observed in only $80.1 \%$ of non-obese diabetic $(p=0.000)$. As against the majority of patients with abdominal obesity (56.12\%) had a BMI below $30 \mathrm{~kg} / \mathrm{m}^{2}$.

\section{Discussion}

Our study found a prevalence of corpuscular obesity (BMI $\geq 30$ ) of $38.5 \%$ in this population of type 2 diabetics. As for the gender, it was $48.5 \%$ in women and $19.1 \%$ in men with a statistically significant difference $(p=0.0001)$. It

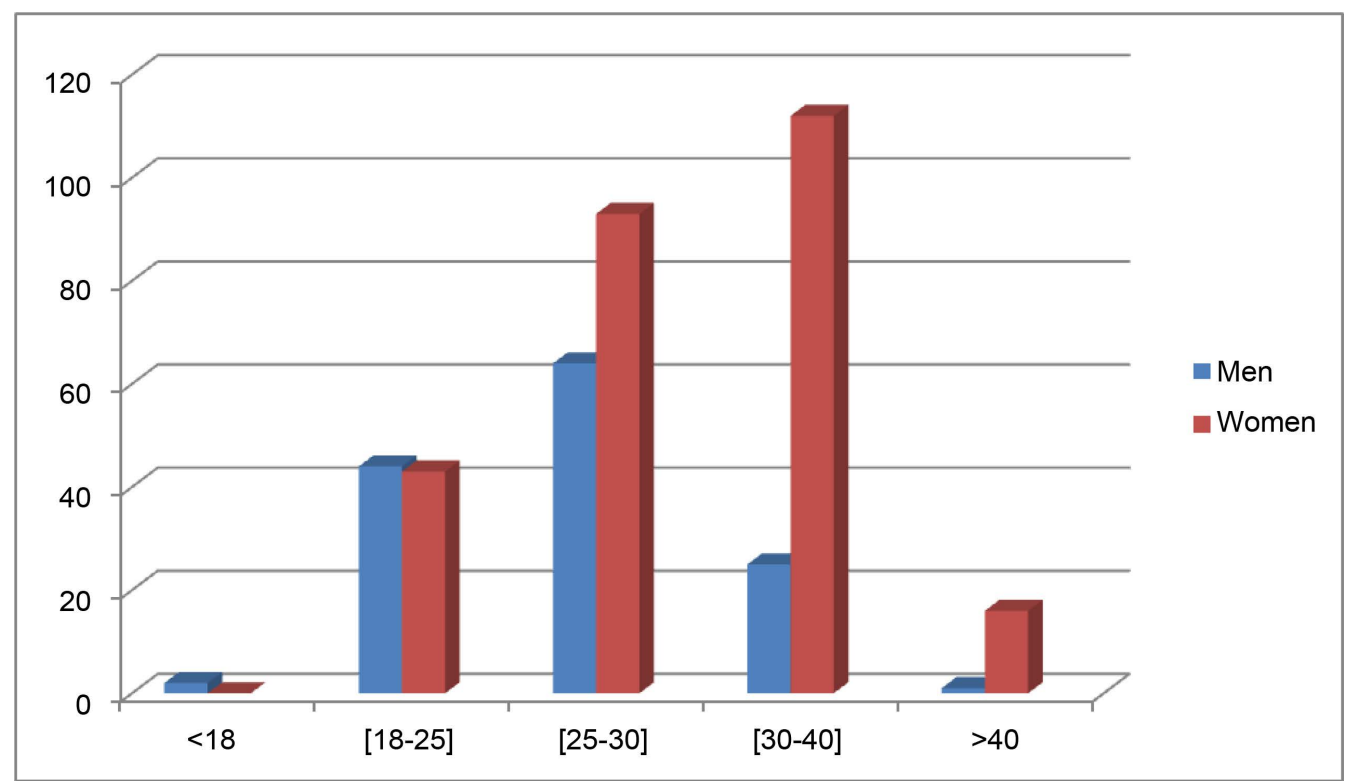

Figure 1. Distribution of patients according to BMI.

Table 1. Distribution of patients according to sex and obesity.

\begin{tabular}{|c|c|c|c|c|c|c|}
\hline & & \multicolumn{2}{|c|}{$\operatorname{Sex}(\%)$} & \multirow{2}{*}{ OR } & \multirow{2}{*}{ CI 95\% } & \multirow{2}{*}{$\mathbf{p}$} \\
\hline & & $\mathbf{M}$ & $\mathbf{F}$ & & & \\
\hline \multirow{2}{*}{ Corpuscular obesity (BMI $\geq 30)$} & Yes & $26(19.1)$ & $128(48.5)$ & \multirow{2}{*}{3.982} & \multirow{2}{*}{$2.437-6.505$} & \multirow{2}{*}{0.0001} \\
\hline & No & $110(80.9)$ & $136(51.5)$ & & & \\
\hline \multirow{2}{*}{ Abdominal obesity } & Yes & $89(65.4)$ & $262(99.2)$ & \multirow{2}{*}{0.014} & \multirow{2}{*}{$0.003-0.061$} & \multirow{2}{*}{0.0001} \\
\hline & No & $47(34.6)$ & $02(0.8)$ & & & \\
\hline
\end{tabular}

Table 2. Crossing between corpuscular obesity and abdominal obesity.

\begin{tabular}{|c|c|c|c|c|c|c|}
\hline & & \multicolumn{2}{|c|}{ Abdominal obesity (\%) } & \multirow{2}{*}{ OR } & \multirow{2}{*}{ CI $95 \%$} & \multirow{2}{*}{$\mathbf{p}$} \\
\hline & & Yes & No & & & \\
\hline \multirow{2}{*}{ Corpuscular obesity } & Yes & $154(100.0)$ & $0(0.0)$ & \multirow{2}{*}{0.000} & \multirow{2}{*}{$0.000-0.082$} & \multirow{2}{*}{0.0001} \\
\hline & No & $197(80.1)$ & 49 (19.9) & & & \\
\hline
\end{tabular}

OR: odds ratio; CI: confidence interval; BMI: Body Mass Index. 
shows that women with diabetes type 2 are more obese than men. The prevalence of obesity in women may be explained by several factors:

- inactivity: trade is the dominant occupation in the study population and the profession is mainly carried out by women who mostly spend the daytime sitting;

- pregnancies: this was shown as a positive association between obesity and the number of pregnancies [7].

In a study of sleep apnea syndrome in type 2 diabetes subjects in Benin, Amoussou-Guénou et al. have noted a corpuscular obesity prevalence of $44.3 \%$ [6].

In our study, the mean BMI of $26.83 \mathrm{~kg} / \mathrm{m}^{2}$ in men and $30.29 \mathrm{~kg} / \mathrm{m}^{2}$ in women with a statistically significant difference $(\mathrm{p}=0.0001)$.

In France, data from the 2001-2007 ENTRED study show that the median Body Mass Index (BMI) of type 2 diabetes subjects is estimated to $29.5 \mathrm{~kg} / \mathrm{m}^{2}$ (value for overweight). Thus, only $20 \%$ of type 2 diabetes subjects are of normal weight $\left(\mathrm{BMI}<25 \mathrm{~kg} / \mathrm{m}^{2}\right), 39 \%$ are overweight $\left(25 \leq \mathrm{BMI}<29 \mathrm{~kg} / \mathrm{m}^{2}\right)$ and $41 \%$ are considered obese (BMI $\left.\geq 30 \mathrm{~kg} / \mathrm{m}^{2}\right)[8]$.

In general, in multiracial population, in 2014 Di Cesare M. et al. found a mean BMI of $24.2 \mathrm{~kg} / \mathrm{m}^{2}$ in men and $24.4 \mathrm{~kg} / \mathrm{m}^{2}$ in women [9].

Obesity leads to many complications responsible for an increase of morbidity and mortality, among them, insulin resistance, especially if obesity is android (metabolic syndrome).

It is complicated by glucose intolerance or diabetes and could also play a role in renal sodium retention, responsible for volume expansion, and increased peripheral vascular resistance, leading to high blood pressure, frequently identified in obese [10].

Regarding abdominal obesity, almost all of the women with diabetes type 2 (99.2\%) had abdominal obesity versus $65.4 \%$ in men $(\mathrm{p}=0.0001)$. The overall prevalence of abdominal obesity in our study population was $87.8 \%$. The mean waist circumference was $97.93 \pm 14.12 \mathrm{~cm}$ with a range of 62.50 and $181.00 \mathrm{~cm}$ for men and $98.89 \pm 12.15 \mathrm{~cm}$ with extremes of 66.00 and 150.00 in women. We therefore find that the prevalence of abdominal obesity is very high $(87.8 \%)$ against $38.5 \%$ for the corpuscular obesity. This demonstrates the primacy of measuring abdominal perimeter compared with BMI.

Most often, obesity linked to diabetes is an androgenic type corresponding to an increased volume of adipocytes located primarily in the abdominal region. Although abdominal fat is less than $20 \%$ of the total fat body mass, its importance is prominent in postprandial lipid management, and both because of its physiology (lipase activity) and anatomy (drainage through the hepatic system). The contribution to the diabetic states that fatty tissue results from the activity of its two components, namely, the abdominal fat itself but also the subcutaneous fat tissue that is present in this area of the body and plays a major role in the synthesis of non-esterified fatty acids. These fabrics are also a source of adipokines, such as PAI-1 (plasminogene activator inhibitor-1), which act on the whole metabolism. Visceral fat accumulation in adipocytes helps maintain a high level of free fatty acids involved also in the development of insulin resistance, particularly hepatic and muscular level, and damage affecting the $\beta$ cells; hence, the importance of systematic measurement of waist circumference among our patients with type 2 . This also allows the systematic investigation of the metabolic syndrome including abdominal obesity is the main criterion as classified by the International Diabetes Federation (IDF).

If the essential physiological role of leptin is a hypothalamic regulation of feeding behavior and energy expenditure [11]-[14], other adipocytokines affect the sensitivity to insulin, so glucose and lipid metabolism, as well as cardiovascular function and inflammatory and immune responses. Among the identified adipokines, adiponectine increases insulin sensitivity and reduces body fat by promoting fatty acid oxidation in muscle, while resistine induced state of insulin resistance, and complications metabolic that result. It has been shown that the production of adiponectine is reduced in obese subjects, whereas resistine is excessive, especially in cases of abdominal obesity associated with insulin resistance and glucose tolerance [15].

The fact that almost all (99.2\%) of the women with diabetes type 2 have a higher waist circumference of 80 $\mathrm{cm}$ does it suggest that the women are really obese and that this threshold of $80 \mathrm{~cm}$ should be reviewed with African black women?

\section{Conclusion}

This study shows a high prevalence of abdominal obesity (87.8\%) in our study population compared to the corpuscular obesity (38.5\%). Hence the importance of measuring waist circumference is more than BMI in diabetic patients. Our study also shows that the diabetic women are more obese than men. In addition, they have almost 
all abdominal obesity $(99.2 \%)$ versus $65.4 \%$ in men with a significant difference $(\mathrm{p}=0.0001)$.

\section{References}

[1] Djrolo, F., Amoussou-Guénou, K.D., Zannou, D.M., Houinato, D., Ahouandogbo, F. and Houngbe, F. (2003) Prevalence of Diabetes Mellitus in Benin. Louvain Médical, 122, S258-S262.

[2] (2008) Rapport final de l'enquête STEPS au Bénin. Direction Nationale de la Projection Sanitaire, National Programme of Fight against Non-Communicable Diseases. Juin.

[3] Amoussou-Guenou, D., Wanvoegbe, A., Hermans, M., Agbodande, A., Boko, M., Amoussou-Guenou Fandi, A. and Kerekou, A. (2015) Prevalence and Risk Factors of Diabetes Mellitus in the Adult Population of Porto-Novo (Benin). Journal of Diabetes Mellitus, 5, 135-140. http://dx.doi.org/10.4236/jdm.2015.53016

[4] Guarignata, L., Whiting, D.R., Beagley, J., Linnenkamp, U., Hambleton, I., Cho, N.H., et al. (2013) Global Estimates of Diabetes Prevalence in Adults for 2013 and Projection for 2035 for the IDF Diabetes Atlas. Diabetes Research and Clinical Practice, 103, 137-149. http://dx.doi.org/10.1016/j.diabres.2013.11.002

[5] Longo-Mbenza, B., Ndungo Kidinda, F., Buassa-Bu-Tsumbu, B., Mbungu Fuele, S. and Vangu Ngoma, D. (2009) Epidemiological and Clinical Profile of Diabetic Foot in the General Hospital in Kinshasa. Médecine d'Afrique Noire, 56, 401-409.

[6] Amoussou-Guenou, K.D., Agbodandé, K.A., Wanvoegbe, F.A., Gnonlonfoun, R., Tchabi, Y., et al. (2015) Sleep Apnea Syndrome in Type 2 Diabetic African in Benin: Prevalence and Associated Factors. Journal of Diabetes and Related Disorders, 1, 102-105.

[7] Rissanen, A.M., Heliovaara, M., Knekt, P., Reunanen, A. and Aromaa, A. (1991) Determinants of Weight Gain and Overweight in Adult Finns. European Journal of Clinical Nutrition, 45, 419-430.

[8] Fagot-Campagna, A., Fosse, S., Roudier, C., Romon, I., Penfornis, A., Lecomte, P., et al. (2009) Characteristics, Vascular Risk and Complications in People with Diabetes in Metropolitan France: Major Developments between ENTRED 2001 and ENTRED 2007. Bulletin Epidémiologique Hebdomadaire, 42-43, 450-455.

[9] Di Cesare, M., Bentham, J., Stevens, G.A., Zhou, B., Danaei, G., Lu, Y., et al. (2016) Trends in Adult Body-Mass Index in 200 Countries from 1975 to 2014: A Pooled Analysis of 1698 Population-Based Measurement Studies with 19·2 Million Participants. The Lancet, 387, 1377-1396. http://dx.doi.org/10.1016/S0140-6736(16)30054-X

[10] Buysschaert, M. (2001) Obesity: From Pathophysiology to Treatment. Louvain Médical, 120, S63-S66.

[11] Considine, R.V. and Caro, J.F. (1999) Pleiotropic Cellular Effects of Leptin. Current Opinion in Endocrinology and Diabetes, 6, 163-169. http://dx.doi.org/10.1097/00060793-199904000-00013

[12] Harris, R.B. (2000) Leptin-Much More than a Satiety Signal. Annual Review of Nutrition, 20, 45-75. http://dx.doi.org/10.1146/annurev.nutr.20.1.45

[13] Ahima, R.S. and Flier, J.S. (2000) Adipose Tissue as an Endocrine Organ. Trends in Endocrinology and Metabolism, 11, 327-332. http://dx.doi.org/10.1016/S1043-2760(00)00301-5

[14] Trayhurn, P. and Beattie, J.H. (2001) Physiological Role of Adipose Tissue: White Adipose Tissue as an Endocrine and Secretory Organ. Proceedings of the Nutrition Society, 60, 329-339. http://dx.doi.org/10.1079/PNS200194

[15] Kolanowski, J. (2003) Role of Adipose Tissue in the Pathogenesis of Obesity and Type 2 Diabetes. Louvain Médical, 122, S223-S231. 


\section{Submit or recommend next manuscript to SCIRP and we will provide best service for you:}

Accepting pre-submission inquiries through Email, Facebook, LinkedIn, Twitter, etc.

A wide selection of journals (inclusive of 9 subjects, more than 200 journals)

Providing 24-hour high-quality service

User-friendly online submission system

Fair and swift peer-review system

Efficient typesetting and proofreading procedure

Display of the result of downloads and visits, as well as the number of cited articles

Maximum dissemination of your research work

Submit your manuscript at: http://papersubmission.scirp.org/ 